\title{
Portuguese as an additional language for academic purposes: contributions from the academic literacies model to course design
}

\author{
Elisa Marchioro Stumpf ${ }^{1}$ \\ Universidade Federal de Pelotas, Pelotas, RS, Brasil
}

\begin{abstract}
We aim at presenting and discussing the proposal of an academic reading and writing course of Portuguese as an additional language for foreign graduate students at a public university in Brazil. The framework guiding the course design comes from the academic literacies model. It highlights social aspects of reading and writing practices, issues of power, authority, and knowledge, and students' identities and meaning-making practices. Grounded on the possibility of using this model for designing writing courses (LILLIS, 2003), we examine how it can help instruction move beyond the text. By showing how its principles took shape in the planning and execution of the course, we discuss its benefits and limitations for this context.
\end{abstract}

Keywords: Portuguese for academic purposes; Additional language; Writing instruction; Academic literacies; Internationalization.

Título: Português como língua adicional para fins acadêmicos: contribuições do modelo de letramentos acadêmicos ao design de cursos

Resumo: Nosso objetivo é apresentar e discutir a proposta de um curso de leitura e produção de textos acadêmicos em português como língua adicional para pós-graduandos estrangeiros em uma universidade brasileira. O quadro teórico que guiou o planejamento do curso vem do modelo de letramentos acadêmicos, que destaca aspectos sociais das práticas de leitura e escrita, além de questões de poder e conhecimento, bem como as identidades dos alunos e práticas de criação de sentido. Considerando a possibilidade de utilizar o modelo para o planejamento de cursos de escrita (LILLIS, 2003), examinamos com ele pode ser útil para expandir o ensino para além do texto. Mostrando como os princípios se materializaram no planejamento e execução do curso, discutimos suas possibilidades e limitações para o contexto.

Palavras-chave: Português para fins acadêmicos; Língua adicional; Ensino de escrita; Letramentos acadêmicos; Internacionalização.

\footnotetext{
${ }^{1}$ Assistant professor of Portuguese as an additional language at the Federal University of Pelotas (UFPel). PhD in Linguistics - Text and Discourse Analysis - received from the Federal University of Rio Grande do Sul (UFRGS). Orcid: https://orcid.org/0000-0002-9080-0903. E-mail: elisa.stumpf@gmail.com
} 


\section{Introduction}

This paper presents some pedagogical implications arising from the implementation of a graduate-level academic reading and writing course in Portuguese as an additional language at the Federal University of Pelotas (UFPel), in Southern Brazil. Specifically, we discuss the possibilities offered by the academic literacies model for going beyond the textual and linguistics levels of analysis and instruction, examining its benefits and limitations regarding our case.

The course was designed as part of internationalization efforts taking place in Brazilian universities that have intensified for at least a decade ${ }^{2}$. According to Molsing and Perna (2015, p. 1),

there has also been a significant increase in incoming foreigners in Brazilian institutions. This is particularly true in higher education, where international institutions and organizations have pursued cooperative agreements in all academic areas with Brazilian higher education institutions (HEIs).

By internationalization, we refer to "the process of integrating an international, intercultural, or global dimension into the purpose, functions or delivery of postsecondary education" (KNIGHT, 2015, p. 2). Integrating an intercultural dimension means considering the possible relationships between nations, cultures, and peoples, even those existing within a country ${ }^{3}$. We focus on the interactions among graduate students from different cultures (national and disciplinary) as they learn the expectations surrounding academic practices in their field and in Brazil.

While many internationalization initiatives aim to send Brazilian students and faculty abroad, the country also receives many foreigners pursuing a course of study, notably from other Latin American countries (ROBLES; BHANDARI, 2017). Even if the similarities between Portuguese and Spanish allow most students to manage their stay in Brazil relatively well, the same cannot be said for graduate students, who are expected to produce complex academic

\footnotetext{
${ }^{2}$ Regarding nationwide language policies, this trend can be observed in at least two different ways. Firstly, the implementation of policies such as the program Language without Borders (LwB Program), established in 2012 to prepare Brazilian students of Science, Technology, Engineering and Mathematics (STEM) for exchange programs abroad. Currently, the program consists mainly of courses of languages such as English, French, German, and Portuguese as L2 for students, professors, and staff of Brazilian public universities to improve foreign language proficiency of the Brazilian academic community (MOLSING; PERNA, 2015). Secondly, the offer of courses entirely taught in English in major universities in what is called English as a Medium of Instruction (EMI), that is, "the use of the English language to teach academic subjects (other than English itself) in countries or jurisdictions where the first language of the majority of the population is not English" (MACARO et al, 2017, p. 37) and mirrors a worldwide trend of English as lingua franca in higher education teaching.

${ }^{3}$ Here, we adopt is a more encompassing concept of culture than that referring to national affiliation or else it would not be possible to talk about academic - or disciplinary - culture(s). Instead, we assume a definition focusing on practices: "cultures are therefore dynamic and emergent - they are created through the actions of individuals and in particular through the ways in which they use language. This means that meanings are not simply shared, coherent constructions about experience but rather can be fragmented, contradictory, and contested within the practices of a social group because they are constituted in moments of interaction (LIDDICOAT; SCARINO, 2013, p. 21).
} 
genres for their degree. To date, however, there are few studies about teaching Portuguese as an additional language (hereafter PAL) for academic purposes; as well as a shortage of resources for this specific audience, which requires instructors to develop materials from scratch or extensively adapt existing ones for speakers of Portuguese as L1.

The most recent book that targets this audience is Passarela (RUANO; CURSINO, 2020), a textbook of Portuguese as a welcoming language for academic purposes for immigrants and refugees attending college. The book is part of a larger program aimed at integrating this audience in the academic context called Brazilian Portuguese for Humanitarian Migration (PBMIH) that takes place at the Federal University of Paraná (UFPR). It was developed for encouraging the permanence of these students at the university; it was created based on four dimensions: the linguistic and methodological content (use of academic genres), the institutional content (explanation of how several institutions inside the university work), cultural content (promotion of cultural diversity and intercultural dialogue), and personal content (valuing the cultures, languages, and life stories of the students).

A short but useful guide for teaching academic genres to foreign students in Brazil was developed by Killner (KILLNER; FURTOSO, 2016), covering abstracts, reviews, articles, and oral presentations. Each unit deals with a single genre and presents a warm-up activity to engage students' prior knowledge, then includes a series of tasks leading the students to examine texts, followed by an extension activity where students can learn more about the topic, and finally, a diagnostic assessment task testing what students have learned so far. Its subsequent analyses (KILLNER; JUNG, 2018, 2019) also shed light on the issue of creating materials that help develop students' academic literacies considered not as neutral and objective knowledge, but as diverse and historically situated practices.

Kuhn (2017) acknowledges the need for research and pedagogical materials to support speakers of Portuguese either as their mother tongue or as an additional language, given the expansion and internationalization of Brazilian higher education and the presence of foreign students in Portugal. Her proposal of a dictionary for university students entailed the construction of a corpus of academic texts in both Brazilian and European Portuguese, which can also foster more research into the lexicogrammatical features of these texts.

While not only dealing with additional languages, reading and writing courses guided by the academic literacies model were reported by Dilli, Morelo and Schlatter (2019), with a detailed analysis of didactic materials. The authors discuss how to incorporate academic literacies principles into reading tasks in language courses for undergraduate indigenous students at a public university in Brazil, arguing that it contributes to their permanence at HEls. The analysis of the task is also useful since it addresses a possible limitation brought by LEA (2004, p. 745) about the possibility of going "further than an 'academic socialization' model in course design", a point to which we come back below.

We begin by describing the context where the course takes place, highlighting aspects that influenced the decisions behind the syllabus. After that, we present a brief literature review where the academic literacies (henceforth AcLits) model is discussed, based on which we propose a list of principles that guided the course design. We then explain how these 
principles took shape in the editions of the course, examining some of the experiences we had in the classroom and conclude by emphasizing the importance of such an approach for academic text production courses.

\section{Teaching context}

As stated before, the course of academic reading and writing in Portuguese for foreign graduate students is an internationalization initiative designed by UFPel to provide linguistic support for the development of academic literacy in an additional language. Before the implementation of the course in 2019, graduate students could take shorter courses offered by the Languages without Borders (LWB) Program, many of which focused on academic reading and writing.

The course is offered by the Office of Graduate Studies, as it belongs to a group of courses open to all graduate students. So far, there have been four classes and almost 30 students have taken it. Most graduate students at the institution come from other Latin American countries, particularly from Colombia, Venezuela, Paraguay, and Mexico. The graduate programs in Plant Protection, Social Memory and Cultural Heritage, and Agronomy receive the largest number of students attending either an MSc/MA or a PhD program. While some research in academic writing instruction recommend students be divided into disciplinespecific courses (a Writing in the Disciplines approach, for example (WINGATE, 2012)), due to the communicative and linguistic features that are unique to each different field of knowledge, this has not been the case for the present course. The implications for teaching a general academic language course (as opposed to discipline-specific courses) are discussed throughout the paper.

\section{Communicative needs of graduate students}

According to Cheng (2018), graduate students, whether writing in their native or a foreign language, constitute a unique group, since they are no longer novice undergraduates nor well-published faculty and yet must grapple with the rules and expectations of scientific communication. Discussing the increasing demand for publication in English from international scholars, he claims that "research English [or Portuguese, in our case] is no one's first language, graduate-level research writing is far from a universal skill, and both research English and graduate-level research writing must be acquired through prolonged education for L2 and L1 writers alike" ${ }^{4}$ (CHENG, 2018, p. 10). Nevertheless, writing in an L2 pose additional issues that have been raised in previous studies, here summarized by Hyland (2003, p. 36) as:

\footnotetext{
${ }^{4}$ This has been attested, in our case, by many native speakers of Portuguese attempting to enroll in the course.
} 
- General composing process patterns seem to be largely similar in L1 and L2.

- Both L1 and L2 skilled writers compose differently from novices.

- Advanced L2 writers are handicapped more by a lack of composing competence than a lack of linguistic competence. The opposite is true for lower proficiency learners.

- L1 writing strategies may or may not be transferred to L2 contexts.

- L2 writers tend to plan less than L1 writers and produce shorter texts.

- L2 writers have more difficulty setting goals and generating material.

- L2 writers revise more but reflect less on their writing.

- L2 writers are less fluent, and produce less accurate and effective texts.

- L2 writers are less inhibited by teacher-editing and feedback.

As the author acknowledges, research on the transfer of L1 literacy to L2 writing is conflicting and some of the issues listed above could easily lead to a deficit perspective when dealing with $\mathrm{L} 2$ writers. In addition, it can be worsened by the fact that they do not necessarily master all the linguistic resources needed for taking part in academic practices in Portuguese, in our case.

Considering that most students have already engaged in academic practices both in their native language (mostly Spanish) or other additional languages (English, in most cases) and, in some cases, even in Portuguese, the course goal is to improve their participation in such practices in Portuguese by appropriating genres and meaning-making resources commonly used in this sphere. To reach this goal, students are expected to discuss and analyze how scientific communication happens in their disciplines, the genres that are used (both for reading and/or writing), and the roles they must fulfill as readers and writers of academic genres.

\section{Course design}

The course was designed based on the premise that texts are produced by people to accomplish actions in the real world. These texts have certain similarities that make it possible to identify them as belonging to a given genre. Each sphere of human activity has its own genres and as we take part in these spheres, we learn how to appropriate each genre. According to the Russian philosopher and scholar Mikhail Bakhtin,

Language is realized in the form of individual concrete utterances (oral and written) by participants in the various areas of human activity. These utterances reflect the specific conditions and goals of each such area not only through their content (thematic) and linguistic style, that is, the selection of the lexical, phraseological, and grammatical resources of the language, but above all through their compositional structure. All three of these aspects - thematic content, style, and compositional structure - are inseparably linked to the whole of the utterance and are equally determined by the specific nature of the particular sphere of communication. Each separate utterance is individual, of course, but each sphere in which language is used develops its own relatively stable types of these utterances. These we may call speech genres (BAKHTIN, 1986, p. 60, original emphasis). 
Considering the activities carried out by participants of the academic sphere, some genres can be selected, such as reviews, oral presentations, posters, articles - review articles, original articles and so on ${ }^{5}$. Each genre serves a particular purpose: articles and oral presentations can convey the findings of a research, while reviews can evaluate these results. As Bakhtin explains (1986), to do so, each text - or "individual concrete utterances" - must: a) refer to a given theme and related topics; b) use a certain repertoire of linguistic resources, and c) display a structure that is recognizable and commonly assigned to a genre. These three aspects work together when classifying a text into a genre; however, they are selected by the speaker based on the communicative function and the people interacting in each situation. Purpose and interlocutors come first and shape the discursive, textual, and linguistic features of a text.

Although we acknowledge that these features overlap and cannot be easily distinguished in a concrete text, the separation into different levels is helpful for analysis and for planning the instruction. We understand discursive features as those that indicate the purpose and communicative roles of the participants; by textual features, we mean coherence and cohesion devices employed by the writer so that a text is understood as a unit; textual features refer to grammatical and lexical choices.

The contents of the course were selected considering the practices in which students engage, the actions they are expected to carry out as a participant of the academic sphere, the genres that support these actions, and the relevant resources embedded in the texts. For the 60-hour course, three genres were chosen to be read/listened to and produced by students: abstract, oral presentation, and article. Other genres were used in the course, such as dictionary entries, e-mails, instructional texts, and lectures, but they were not studied indepth.

While it is not possible to foresee and choose all linguistic features before getting to know each group of students, citation, references, and aspects of formal written register were selected, with the possibility of adapting the instruction according to the group of students enrolled each semester. In addition, other linguistic features can be added considering that students are learning Portuguese as an additional language. Since the curriculum is not guided by a progression of grammar topics (as it is mostly the case for regular language courses using textbooks), both simple and more complex linguistic resources can be included, as long as they are necessary to read and produce the texts selected for the course.

It is important to highlight that these linguistic resources were analyzed in the context where they appear, since meaning can only be attributed within a concrete text and communicative situation. Therefore, the texts are not merely an excuse to work with grammar but are the basis for instruction - just as the genres are the structuring element of the curriculum (SCHLATTER; GARCEZ, 2012). Moreover, the language features need to be studied

\footnotetext{
${ }^{5}$ A didactic model for the study of articles is presented by Rosa (2019), based on the principles from Didactic of genres (DOLZ; SCHNEUWLY, 2004 apud ROSA, 2019). From the analysis of 10 articles (5 from Law and 5 from Pharmaceutical Sciences), the author shows how their linguistics features are linked to the research practices in different fields. According to the author (ROSA, 2019), the didactic model serves to integrate students in communicative practices in academia.
} 
through their meaning and function in each particular text, as it is not possible to assign each structure a function in advance, without considering the linguistic and social context surrounding their usage in each unique text.

\section{The academic literacies (AcLits) model}

We now turn to the contributions from the AcLits model (LEA, 2004; LEA; STREET, 2006) to the course design, since our goal was to create a space where students could reflect on their writing practices in academia, taking into account issues such as and students' backgrounds, literacy practices and identities.

Research about reading and writing practices went through a significant change with the advent of the New Literacy Studies. This framework includes studies that, beginning in the 1980s, advocated for a sociocultural approach of literacy practices, different from other perspectives which pay more attention to cognitive aspects. By offering a detailed description of such practices, authors such as Heath (1983) and Street (1984), among others, pointed to the existence of diverse practices and showed how some are valued over others in institutional discourses.

These studies also cast doubt on some assumptions about the processes of reading and writing. Previously, it was widely believed that they consisted of a set of individual and cognitive skills that, once mastered, would have a significant impact on an individual's life, ranging from cognitive to social benefits. This is what Street (1984) called the autonomous model of literacy, opposed to the ideological one, which reveals that these beliefs are not neutral and that literacy practices are always socially and historically situated. According to Lillis (2001, p. 37, original emphasis), "in writings often referred to currently as 'New Literacy Studies', the notion of literacies and literacy practices, rather than literacy has come to reflect a growing understanding of literacies as multiple and socially situated."

Studies drawing on this approach also shed light on writing instruction in higher education settings, pointing out its remedial and generic (i.e., not specific to any discipline) character. They also devised three distinct models to account for the teaching of writing in these settings: study skills, academic socialization, and academic literacies. The first model is based on the assumption that literacy "is a set of atomised skills which students have to learn and which are then transferable to other contexts" (LEA; STREET, 1998, p. 158), since only the surface features of language are regarded (LEA; STREET, 2006, p. 368).

The second model advocates that the student must be inducted into the academic culture by his/her professors. Though it is more encompassing than the first model and takes into account sociocultural aspects, this perspective also suffered criticism for considering academic culture as homogeneous and as something to which students can adapt to by the mere fact of having access to it.

The third model highlights the social aspect of literacy practices and the identities created by their participants. It also considers the existence of an academic culture, but frames it related to issues of discourse and power. The underlying practices of this academic culture 
are varied, as well as the roles of the participants. This model challenges the existence of a neutral set of skills that, once learned, could be used independently from its context. From this perspective, it is possible to criticize the idea of simply inducting the students into academic practices, since these are subject to change, and their participants need to negotiate the expectations surrounding them.

By making the differences among the three models explicit, the authors underline the fact that they are not mutually exclusive. Instead, the three models overlap, so that each encompasses features of the former model. The academic literacies model contains the others while also offering a broader characterization of literacy practices, as it acknowledges that "literacies are heterogeneous, are shaped by interests, epistemologies and power relations, have consequences for identity and are open to contestation and change" (IVANIC, 2004, p. 222). According to this model, one cannot construe some literacies as inherently better than others but should aim at understanding the situated functioning of these practices.

Research carried out on AcLits deal with different contexts of higher education, with results indicating a complex relationship between the development of disciplinary knowledge and writing practices. Students display difficulties in unveiling rules for writing in some contexts (LEA, 2004, p. 740). Besides, they also show that many professors and instructors use different and/or vague criteria when evaluating assignments. Therefore, students that are not acculturated into their fields may have trouble in identifying clearly what is expected from them, while some professors are also not able to explain their expectations for the assignments.

With a strong critical stance, the AcLits model has only recently shifted its focus to think about issues of pedagogy, yet, so far, there is no definite nor distinct writing methodology derived from these studies. This claim is reinforced by Lillis's observation that "academic literacies has yet to be developed as a design frame (Kress, 1998, 2000) which can actively contribute to student writing pedagogy as both theory and practice" (2003, p. 192, original emphasis). However, scholars have stated some principles that can guide course design and the development of instructional materials (LEA, 2004; LILLIS, 2003).

Lillis' proposal draws on Bakhtin's dialogism to challenge standard authoritative practices in academic writing instruction employing three suggestions. The first is giving opportunities for talkback, and not feedback, around texts; that is, instead of considering the text as a product, "focusing on the student's text in process, an acknowledgement of the partial nature of any text and hence the range of potential meanings" (LILLIS, 2003, p. 204). The second suggestion is the reconsideration of what is deemed as valid academic knowledge, which is a historical and discipline-situated construction and, therefore, open to contestation. The third is related to the second and refers to an increasing number of genres accepted in higher education besides the essay. With rapidly evolving publication demands and the desire to reach a broader audience, there seems to be more room lately for other ways of communicating science outside academia.

Lea (2004) analyses the experience of deriving a writing pedagogy from the academic literacies principles for an online course targeted at MA students from several disciplines - 
which particularly fits our multidisciplinary context. From this experience, she puts together a list of principles for course design following an AcLits approach, of which we highlight the following:

- Takes account of students' present and previous literacy practices.

- Acknowledges that texts do more than represent knowledge.

$[\ldots]$

- Recognizes the gaps between students' and tutors' expectations and understanding of the texts involved in learning.

$[\ldots]$

- Attempts to create spaces for exploration of different meanings and understandings by all course participants.

- Does not create a dichotomy between other literacies and academic literacies.

- Recognizes and builds upon issues of identity and how these are implicated in the creation of texts.

- Acknowledges the power dimensions of institutional structures and procedures and the ways that these are implicated in text production.

- Rather than trying to acculturate students into a discipline, attempts to see students as engaged participants in the practices and texts which they encounter during their study of the course.

[...] (LEA, 2004, p. 744).

Issues of linguistic meaning and text production, students' learning experiences and literacy practices, and epistemology and the production of knowledge are all intertwined in these principles and suggestions. Our challenge was to find ways to incorporate these principles in all instances of course design: lesson planning and delivery, creation of instructional material, and assessment procedures. We aimed not only at having students read and produce academic genres, but also critically reflect on and engage in a dialogue about their experiences as L2 writers in a graduate program.

Table 1 - Summary of guiding principles based on Lea (2004) and Lillis (2003)

\begin{tabular}{|c|c|c|}
\hline Meaning and text production & $\begin{array}{l}\text { Students' learning experiences } \\
\text { and literacy practices }\end{array}$ & $\begin{array}{l}\text { Epistemology and production } \\
\text { of knowledge }\end{array}$ \\
\hline $\begin{array}{l}\text { Acknowledgement of the } \\
\text { uniqueness of each concrete } \\
\text { text and the play between } \\
\text { regular and singular at stake in } \\
\text { writing. }\end{array}$ & $\begin{array}{l}\text { Raising students' awareness of } \\
\text { disciplinary practices by } \\
\text { recognizing them as legitimate } \\
\text { participants. }\end{array}$ & $\begin{array}{l}\text { Discussion about how texts } \\
\text { represent, create, and shape } \\
\text { knowledge. }\end{array}$ \\
\hline $\begin{array}{l}\text { Meaning is not stable and is } \\
\text { open to contestation by all } \\
\text { participants. }\end{array}$ & $\begin{array}{l}\text { Considering students' learning } \\
\text { experiences and literacy } \\
\text { practices (past and current) } \\
\text { both inside and outside } \\
\text { academia. }\end{array}$ & $\begin{array}{l}\text { Establishment of critical } \\
\text { reflection about the } \\
\text { (sometimes) hidden power } \\
\text { dimensions in institutions and } \\
\text { their outreach. }\end{array}$ \\
\hline $\begin{array}{l}\text { Discussion of other genres, } \\
\text { particularly newer genres in the } \\
\text { academic context. }\end{array}$ & $\begin{array}{l}\text { Acknowledgement of the } \\
\text { identities built as students } \\
\text { engage in literacy practices. }\end{array}$ & $\begin{array}{l}\text { Reconsideration of what is } \\
\text { considered as valid academic } \\
\text { knowledge. }\end{array}$ \\
\hline
\end{tabular}






Source: author (2020)

\section{Implementing AcLits principles in the classroom}

To explain and exemplify how the principles outlined above were put into practice in the three editions of the course (as of August 2020), we examine how they informed the decisions for designing the course. We also discuss how we incorporated the principles, their benefits, and possible limitations. As stated earlier, all versions of the course attempted to incorporate some of the orientations.

\section{Course syllabus - what to teach and how to evaluate}

As explained above, the course content was selected by means of analyzing the practices in which participants of the academic sphere were expected to engage. For our purposes, we picked presenting a research article and evaluating other researchers' activities and results. The genres used for carrying out such actions were abstracts, articles - both original and review papers - reviews, and oral presentations. While those genres were listed under the contents, each group of students could have a say about where the attention should go to.

This happened, for example, when a group claimed that reviews were not a common genre in their field of study. Indeed, a quick search of the main journals endorsed their position since most of them did not list reviews as a type of manuscript accepted for submission. Their task was then finding which genres could be used in their area to express a point of view about recent findings and developments in the field. These texts are commonly referred to as opinion, perspective, or point of view articles. A hypothesis advanced by students was that reviews deal mostly with research published in a book format, which is getting more and more uncommon in their field, as the time it takes to submit and publish one may mean that some results might be already outdated when it reaches the readers - which could also be attested by publication guidelines discouraging references to books and favoring the use of recent articles. This reasoning, in turn, led to a classroom discussion about how knowledge is produced, by whom, and how long it takes. Students also talked about what constitutes valid knowledge in some areas and who are the stakeholders involved in this tacit decision.

This serves to illustrate how a considerably simple decision - what content to cover in the course - gave rise to a complex set of questions and hypotheses put forward by students. This would not have happened had the instructor not included students in making the decision, which shows the relevance of having students actively involved in their learning, or, 
as Lea (2004, p. 744) frames it, seeing "the course as mediated by different participants. [Allowing] spaces for this and [embedding] this in both the course content and the course design".

Most of the material was developed specifically for the course. Besides the possibility of catering to students' needs, disciplines, and interests, this was also due to a shortage of materials for teaching Portuguese as an additional language for academic purposes. Most academic reading and writing materials in Portuguese are designed for native speakers; on the other hand, PAL textbooks hardly cover linguistic and discursive features needed for academic writing.

While during the first two editions most texts were related to students' disciplines and research interests, the last edition also contained texts about transversal topics such as plagiarism, predatory journals, and mental health and gender inequality in academia. As more attention is given to those issues, we thought that they would also elicit students' opinions about their experiences in HEls and help them navigate academia. Students are asked to create a small corpus of sample research texts from their disciplines and tasks are assigned to help them examine linguistic and textual features, such as verb tense in abstracts and types of citations. This fosters students' autonomy and makes it possible to deal with different disciplinary writing traditions on the same course. It may also be an answer to Lea's (2004, p. 745) question: "how do designers provide pedagogic spaces for exploration of all the different and contrasting textual practices that are involved in teaching and learning?". It is important to keep in mind that one factor making this task easier was the relatively small number of students in each group (around 12), which made it possible for such a guided analysis of texts from different disciplines. Discussing plagiarism, demands for publishing, and the existence of predatory journals also helps to broach issues such as the responsibility of the participants in academia, which in turn points to power relations embedded in the institutional regulations.

Another important feature of the syllabus is related to the assessment. Students are expected and encouraged to rewrite their texts based on the feedback given by the instructor and, for some texts, a peer review by their classmates. Both the feedback and the review contain the criteria decided by the group after studying a genre. This is an attempt at making visible both the expectations surrounding a given task and the features of a text, so that students know what is expected from them. However, it does not mean that the criteria form a model to which students should conform, but rather that they are guidelines for helping them achieve what students and instructor have judged as adequate texts (considering genre features such as purpose, context, and interlocutors).

Another side benefit assumed from this practice is that it can potentially help students to negotiate these expectations around written assignments with other professors. Our aim with this is to tackle a limitation pointed by Lea (2004), who raises the question of whether being explicit about texts is enough - and to and to which extent it can be done. While another type of study should be conducted to actually examine this issue in our case, students might feel empowered, since they have the tools (i.e., master the vocabulary) to talk about texts and the writing process. 
The process of feedback and rewriting is also an opportunity for negotiating meaning. Language is not a transparent means of communication employed unequivocally by people. Therefore, meaning construed by participants not only is not obvious, it is shaped by context and disputable by those engaging in literacy practices. It should be noted, however, that not all students seem to feel comfortable in playing such an active role in their learning. One possible reason is the prevalence of traditional educational approaches in which they are expected to remain passive and agree with the instructor.

Opening room for discussion - literacy practices inside and outside academia

While the consideration of how literacy practices are culturally situated, influenced by formal education and shaped by the readers' purposes is raised throughout the course, there are moments where these issues come to the forefront of debate. One way of doing so is explaining to students the framework behind the course and showing how it is supported by research. Thus, aspects that they might have considered strictly personal (how they write) or dictated by a set of rules and prescriptions (how they should write) are also a fertile research area.

In the three editions of the course, this talk was encouraged after reading excerpts of an interview with David Russel (RUSSEL, 2009) dealing with the differences between reading and writing at school and at university level, the functions of academic writing, and the different disciplinary traditions. The answers are debated and expanded to encourage students to reflect on their literacy practices throughout their lives, in different moments and contexts, so that they can share their experiences and understand all the issues at stake when writing at graduate level. Students are encouraged to write down more questions about the topic, so that the group can come back to those questions throughout the semester and check whether they have answered their doubts.

Another purpose for showing students research about academic writing is to discuss that part of the advice they had about writing (usually in the form of strict rules regarding textual and linguistic features) may need to be reconsidered in light of descriptive research and not prescriptive rules for writing. However, one could claim that this practice only reifies the importance assigned to certain types of knowledge (that worth being published, for example) and disregards others. We argue that it helps students to realize that academic writing is not like following a recipe and there are no universally valid and permanent recommendations - which is also done through the analysis of students' own set of texts, as explained above. According to Wingate (2012, p. 28), "it has been long acknowledged that writing instruction must go beyond a prescriptive initiation into disciplinary conventions (e.g., Tribble, 1996) and enable students to take a critical view of the context of these conventions".

Having shown and examined how some principles deriving from the AcLits model informed the course design, it is important to discuss a limitation that we have raised before: "is it possible to go further than an 'academic socialization' model in course design?" (LEA, 2004, p. 745). Even with all attempts at making the AcLits perspective incorporated in the 
syllabus and the tasks, it seems to be the instructor's role to lead the discussion towards a critical instance about the issues arising from academic writing. As some authors have acknowledged (LILLIS, 2003; LEA, 2004), AcLits is a powerful critique frame to challenge dominant discourses about literacy practices. While careful course design can steer the participants towards this perspective, it ultimately depends on the instructor to provide space for this discussion. Even if AcLits has not been developed as a teaching methodology, it can inform and shape teaching practices.

\section{Final remarks}

This paper sheds light on a topic addressed by few researchers: the development of courses of Portuguese as an additional language for academic purposes. Although there is a considerable number of materials for writing instruction targeting native Portuguese speakers, the specific needs of L2 Portuguese speakers at graduate level are not being met. There is a need for more research into all aspects involved in the teaching of academic writing for speakers of other languages, including the Brazilian sign language (LIBRAS), as currently more deaf students can enter HEls. To strengthen and improve the course tasks we outlined above, the next step in our research project is gathering students' perspectives on their learning experiences in the course. Other challenges lying ahead include shifting the course to a remote instruction format, which can also yield new experiences in a completely digital teaching environment.

Moreover, we aimed at discussing whether the AcLits model could be a useful framework for enhancing the instruction so that it includes more overarching issues related to academic writing. This perspective can provide instructors with relevant insight into aspects of power relations, literacy practices, and students' experiences in academia. Therefore, incorporating AcLits principles in the classroom can be beneficial for graduate students, since it promotes critical reflection on issues pertaining to the academic context, increasing transdisciplinary dialogue and collaboration. We believe that this perspective can empower students in their academic writing endeavors, since they are recognized as legitimate participants of activities carried out through oral and written texts. Considering that many graduate students may follow an academic career path, it would also be a valuable addition to their research skills, since they will be better equipped to advise other students and/or peers concerning academic writing practices.

\section{References}

BAKHTIN, M. The problem of speech genres. In: EMERSON, C.; HOLQUIST, M. (Orgs.). Speech genres and other late essays. Austin: University of Texas Press, 1986.

CHENG, An. Genre and graduate-level research writing. Ann Arbor, US: University of Michigan Press, 2018. Kindle Edition. https://doi.org/10.3998/mpub.9558175 
DILLI, C.; MORELO, B.; SCHLATTER, M. O ensino de leitura voltado a universitários indígenas: análise de uma unidade didática à luz dos estudos de letramento acadêmico. Revista Linguagem \& Ensino, v. 22, n. 3, p. 666-688, 2019. https://doi.org/10.15210/rle.v22i3.17145

HEATH, S. B. Ways with words: language, life, and work in communities and classrooms. Cambridge: CUP, 1983. https://doi.org/10.1017/CBO9780511841057

HYLAND, K. Second language writing. Cambridge: CUP, 2003.

https://doi.org/10.1017/CBO9780511667251

IVANIC, R. Discourses of writing and learning to write. Language and Education, v. 18, n. 3, p. 220-245, 2004. https://doi.org/10.1080/09500780408666877

KILLNER, M.; FURTOSO, V. A. B. Roteiro didático para o ensino de PLE em contexto acadêmico. Londrina: UEL, 2016.

KILLNER, M.; JUNG, N. M. Letramento acadêmico em contexto de ensino de português como PLE/PLA: uma análise da unidade didática Artigo Acadêmico. Belt - Brazilian English Language Teaching Journal, v. 10, n. 1, p. 3235-3382, 2019. https://doi.org/10.15448/2178$\underline{3640.2019 .1 .33235}$

KILLNER, M.; JUNG, N. M. Letramento em contexto acadêmico: análise de material de português para estrangeiros. In: SIMPÓSIO SIPLE 2017, 2017, Lisboa. Anais do Simpósio SIPLE 2017. Londrina: SIPLE, 2018. p.226 - 238.

KNIGHT, J. Updated Definition of Internationalization. International Higher Education, n. 33, p. 2-3, 2015. https://doi.org/10.6017/ihe.2003.33.7391

KUHN, T. Z. A design proposal of an online corpus-driven dictionary of Portuguese for University Students. 2017. 421 f. Tese (Doutorado). Universidade de Lisboa, Lisboa, 2017.

LEA, M. Academic Literacies: a pedagogy for course design. Studies in Higher Education, v. 29, n. 6, p.739-756, 2004. https://doi.org/10.1080/0307507042000287230

LEA, M. R.; STREET, B. V. Student writing in higher education: an academic literacies approach. Studies in Higher Education, v. 23, n. 2, p. 157-172, 1998.

https://doi.org/10.1080/03075079812331380364

LEA, M. R.; STREET, B. V. The "academic literacies" model: theory and applications. Theory into practice, v. 45, n. 4, p.368-377, 2006. https://doi.org/10.1207/s15430421tip4504 11

LIDDICOAT, A.; SCARINO, A. Intercultural language teaching and learning. Oxford: WileyBlackwell, 2013. https://doi.org/10.1002/9781118482070

LILLIS, T. Student writing: access, regulation, desire. London: Routledge, 2001. https://doi.org/10.4324/9780203186268

LILLIS, T. Student writing as 'academic literacies': drawing on Bakhtin to move from critique to design. Language and Education, v. 17, n. 3, p. 192-207, 2003. https://doi.org/10.1080/09500780308666848

MACARO, E. et al. A systematic review of English medium instruction in higher education. Language Teaching, v. 51, n. 01, p. 36-76, 2017. https://doi.org/10.1017/S0261444817000350

MOLSING, K. V.; LOPES-PERNA, C. B. Research and teaching in Portuguese for Specific Purposes. Belt - Brazilian English Language Teaching Journal, v. 5, n. 2, p. 17. https://doi.org/10.15448/2178-3640.2014.2.19701 
ROSA, R. A. Modelo didático do gênero artigo científico: um contributo para o ensino do Português como Língua Adicional. BELT - Brazilian English Language Teaching Journal, v. 10, n. 1, p. e33154, 2019. https://doi.org/10.15448/2178-3640.2019.1.33154

ROBLES, C.; BHANDARI, R. Higher Education and Student Mobility: a capacity building pilot study in Brazil, 2017.

RUANO, B. P.; CURSINO, C. (Orgs.). Passarela: português como língua de acolhimento para fins acadêmicos. Curitiba: Editora Peregrina, 2020.

RUSSEL, D. Letramento acadêmico: leitura e escrita na universidade. [Entrevista concedida a] Flávia Brocchetto Ramos e Vânia Marta Espeiorin. Conjecturas, Caxias do Sul, v. 14, n. 2, p. 241-247, maio/ago, 2009.

SCHLATTER, M.; GARCEZ, P. Línguas adicionais na escola: aprendizagens colaborativas em inglês. Erechim: Edelbra, 2012.

STREET, B.V. Literacy in theory and practice. Cambridge: CUP, 1984.

WINGATE, U. Using Academic Literacies and genre-based models for academic writing instruction: a "literacy" journey. Journal of English For Academic Purposes, [S.L.], v. 11, n. 1, p. 26-37, mar. 2012. https://doi.org/10.1016/j.jeap.2011.11.006

Recebido em: 09/08/2020.

Aceito em: 16/10/2020. 